\title{
DINAMIKA PENERIMAAN SOSIAL TEKNOLOGI BIOGAS DI KOMUNITAS PEDESAANINDONESIA: STUDI KASUS DI DAERAH ISTIWEWA YOGYAKARTA
}

\author{
THE DYNAMIC OF SOCIAL ACCEPTANCE OF BIOGAS TECHNOLOGY \\ IN RURAL COMMUNITY OF INDONESIA: CASE STUDY OF \\ YOGYAKARTA SPECIAL REGION
}

Meredian Alam¹, Niken Budi Pratiwi²

(Diterima tanggal 15-11-2011; Disetujui tanggal 14-03-2012)

\begin{abstract}
ABSTRAK
Kenaikan harga bahan bakar bensin dan LPG (Liquified Petroleum Gas) telah meningkatkan kekhawatiran di kalangan masyarakat lokal di pedesaan Indonesia, terutama mereka yang bekerja di industri lokal kecil. Situasi ini memotivasi masyarakat untuk menggunakan biogas sebagai pengganti bahan bakar alternatif dalam rangka mempertahankan industri kecil rumahan mereka dan ekonomi domestik karena efisiensi biogas dianggap cukup terjangkau dan relatif aman. Selain itu, penggunaan biogas cocok dipakai di Indonesia karena jumlah ternak di daerah pedesaan memberikan kontribusi terhadap proses gasifikasi kimia mengubah kotoran menjadi metana-gas di mesin fermentasi, yang nantinya dapat digunakan untuk memasak. Pengembangan gas di daerah pedesaan terutama didasarkan pada inisiatif masyarakat dengan bantuan dari Lembaga Swadaya Masyarakat dan pemangku kepentingan universitas, namun pemerintah daerah belum terlibat secara aktif. Tulisan ini mencoba untuk mengungkap faktor-faktor memfasilitasi dalam masyarakat dan beberapa perbaikan yang pemerintah daerah harus melakukan sebagai cara untuk mendukung ketahanan pangan dan mata pencaharian lokal. Partisipasi lokal di sini kemudian diperhitungkan untuk pengoperasian biogas yang sukses.
\end{abstract}

Kata Kunci: biogas, energi terbarukan, komunitas

\begin{abstract}
A rapid increase in gasoline and other LPG (Liquified Petroleum Gas) price has been raising concerns among local communities in rural Indonesia, especially those who work in small local enterprises. This situation motivates people to use biogas as fuel replacement in order to improve their home industry and domestic economy as biogas is considered affordable enough and relatively safe. Other than this, the use of biogas is best utilized in Indonesia because the total number of cattle in rural areas contributes to the/a reacting gasification processes by chemically converting the dung into methane-gas in fermentation machines, which later can be used for cooking. The development of gas in rural areas is mainly based on community initiatives with the assistance of Non-Government Organizations and university stakeholders, but the local government has not been actively involved. This paper attempts to uncover the facilitating factors in communities and some improvements that local government must undertake as a way to support food security and local livelihoods. Local participation here is then taken into account for successful biogas operations
\end{abstract}

Keywords: biogas, renewable energy, community

\section{INTRODUCTION}

Although the government of Indonesia has people significantly, especially those who reinforced oil subsidy, this does not help live in rural areas. Economic crisis raise

\footnotetext{
${ }^{1}$ Department of Sociology Faculty of Social and Political Sciences, Jln Socio-Yudisia No. 1 Bulaksumur, Sleman, Yogyakarta 55283.

E-mail: mere.alam@gmail.com

${ }^{2}$ Center for Environment Studies, Gadjah Mada University, Jln. Kebudayaan, Sleman, Yogyakarta. E-mail: niken.b.pratiwi@gmail.com
} 
concerns from the community that will potentially make them collapsed if there is no feasible solution. The increase in LPG (Liquified Petroleum Gas) price and also oil, as researched by Wahyuni (2008), is regarded costly for the community and based on this, alternative renewable such biogas gain its importance. The use of biogas is essentially to improve community's economic capacity and generate income as they are able to save money by reducing production costs. There are 12714181 cattles in the agricultural sector of Indonesia and they could feasibly provide ample inputs as biogas chemical activators (Directorate of Livestock Indonesia, 2010). Most of the cattle farms are situated in Yogyakarta Special Province, West Java, East Java, South Sumatra, and West Sumatra. By producing biogas, GHG (Green House Gas) emissions can be effectively reduced in the atmosphere, where methane counts for $70 \%$ among other GHG gases. It also has 21 times of the hazardous effect for human well-being compared to carbon dioxide (Widodo and Hendriadi, 2005). Larson and Kartha (2000) emphasize, the cycle of GHG effect can be gradually halted if dual efforts of using biogas and encouraging the locals to stop consuming fossil-based fuel. An estimation suggests that by 2050 almost $30 \%$ of the global primary energy consumption will be covered by regenerative energy sources (see Deublein \& Steinhauser, 2008).

Indonesian energy consumption is dependent on oil and gas production. Although the oil and gas industry has grown rapidly from 1970 to 2001, Abdullah (2005) argues that in 18 years, oil and gas will be depleted. The urgency of replacing oil usage should be inclusive in the government of Indonesia agenda as it is enshrined in the Kyoto Protocol, ratified on February 162005 (Wahyuni, 2008). The management of biogas under a renewable energy platform at the national level should be prioritized by the government to overcome energy scarcity ${ }^{3}$. The problem of financial accessibility to such energy is mostly faced by the rural communities and therefore the policy implications should be directed in that way.

Those problem become national prominence in Indonesia, thus by examining two different case studies about the following alternative energy implementation, this paper aims to analyze the facilitating dimension of biogas at the local level and the degree of government involvement in sustaining actions and local initiatives. The importance of examining the government involvement in environmental changes is to scrutinize how far their involvement in planning stage because government is ideally responsible for setting up policy that is compatible with local need. Further more, government action in biogas development is barely discussed in the research agenda. Barnet, et al (1978) state that building biogas technology must be facilitated by the active actions of local government and this is an important point to highlight. Embarking from this starting point, local participation as a core extent of development

\footnotetext{
${ }^{3}$ As part of regional preparation of shared Asia Pacific Perspective on the issue for CSD-9 (UN Commissions on Sustainable Developmeny its 9th session), the minister and heads of the delegations attending the High Level Meeting on Energy for Sustainable Development in Bali Indonesia 2000. The declaration together with Sustainable Development Action Program and Implementation Modalities for the Asia and Pacific Region 2001-2005 serve as agenda for taking firm step toward sustainable development, but viable renewable technologies are not well-popularized and dominated by government subsidy to fosil oil (see Saha, 2003)
} 
is elaborated in the next section of the paper. Studies and policy implications are outlined to encourage a strategic system within the relations of government, community, and other stakeholders, presented in the developing countries setting.

\section{BIOGAS OPERATION}

Before continuing to examine the research sites, the environmental benefit of biogas is presented. Biogas as part of biomass was actually developed in pre-industrial times. However, it was a period where the complexity of human need had not been pushing forward consumption demand. Nevertheless, biogas remains suitable for the current need in developing countries to overcome energy scarcity (Reijenders, 2006). Each 1 cubic meter of biogas output is equal to $0.46 \mathrm{~kg}$ of LPG, 0.62 litre of kerosene (Wahyuni, 2008). In terms of cooking activities, it may contribute to 3 meals for a family of 5-6 members and replace $0.7 \mathrm{~kg}$ of petrol (www. paceproject.net). Basically, biogas consists of a mixture of roughly $65 \%$ of methane, $30 \%$ carbon $\left(\mathrm{CO}_{x}\right)$, and $1 \%$ hydrogen sulfide $\left(\mathrm{H}_{2} \mathrm{~S}\right)$ (Da Silva, 1980).

The design of biogas plants shall be comply to the technical requirements to allow its sustainability. As enshrined by Karki et al (2005), C/N Ratio, pH, Digestion Temperature, and Retention Time are four essential parameters to be taken into account. $\mathrm{C} / \mathrm{N}$ Ratio is defined as proportion of carbon to nitrogen exist in the organic matter. The gas production is construed extractable if $\mathrm{C} / \mathrm{N}$ ration is between 20 and 30 . The $\mathrm{pH}$ is the measure of acidity/alkalinity of the input and it is neutral if reaching 7 while above 7 is alkaline. The gas output in must prevail the $\mathrm{pH}$ value of 6-7. Digestion temperature is related to the most suitable temperature of place where the biogas plants installed. The temperature between $20^{\circ}-35^{\circ} \mathrm{C}$ is regarded best fitted to enable gas production. Therefore, biogas technology is not feasible in a cold climate. The retention time is an average time that a given quantity of input remains in the digester (Karki et al 2005:13). The following table summarizes the technical requirement:

Table 1 Design Parameters of Biogas Plant

\begin{tabular}{|c|l|l|}
\hline No & Parameter & Value \\
\hline 1 & C/N Ratio & $20-30$ \\
\hline 2 & $\mathrm{pH}$ & $6-7$ \\
\hline 3 & Digestion Temperature & $20^{\circ}-35^{\circ} \mathrm{C}$ \\
\hline 4 & Retention Time & $40-100$ days \\
\hline 5 & Biogas Energy Content & $6 \mathrm{kWh} / \mathrm{m}^{3}$ \\
\hline 6 & Yielding of cow dung & $9-15 \mathrm{~kg} / \mathrm{day}$ \\
\hline 7 & Gas production per kg of cow dung & $0.023-0.04 \mathrm{~m}^{3}$ \\
\hline 8 & Gas requirement for cooking & $0.2-0.3 \mathrm{~m}^{3} / \mathrm{person}$ \\
\hline
\end{tabular}

Source: Karki et al (2005 


\section{RESULT AND ANALYSIS}

Two different implementations and biogas practices are discussed to compare the characteristics of local participation, government involvement, and emergence of other stakeholders such as a university providing technical assessments. Banyakan village research site I (see map below-blue dot) shows that biogas is used for domestic uses and by the local government, including the head of county and the village chief. The community in Manis Renggo, as research site II (see map below-orange dot), have more capabilities in biogas usage to leverage productivity. The local government especially represented by the village chief support the local initiatives by performing regular consultation with the Gadjah Mada University experts on biogas technology The location is determinant to what kind of biogas plant is used by the community. Banyakan is situated in Bantul district which was severely devastated by the earthquake in 2006 and so the digester is made of PVC pipes which are considered durable against future earthquakes.

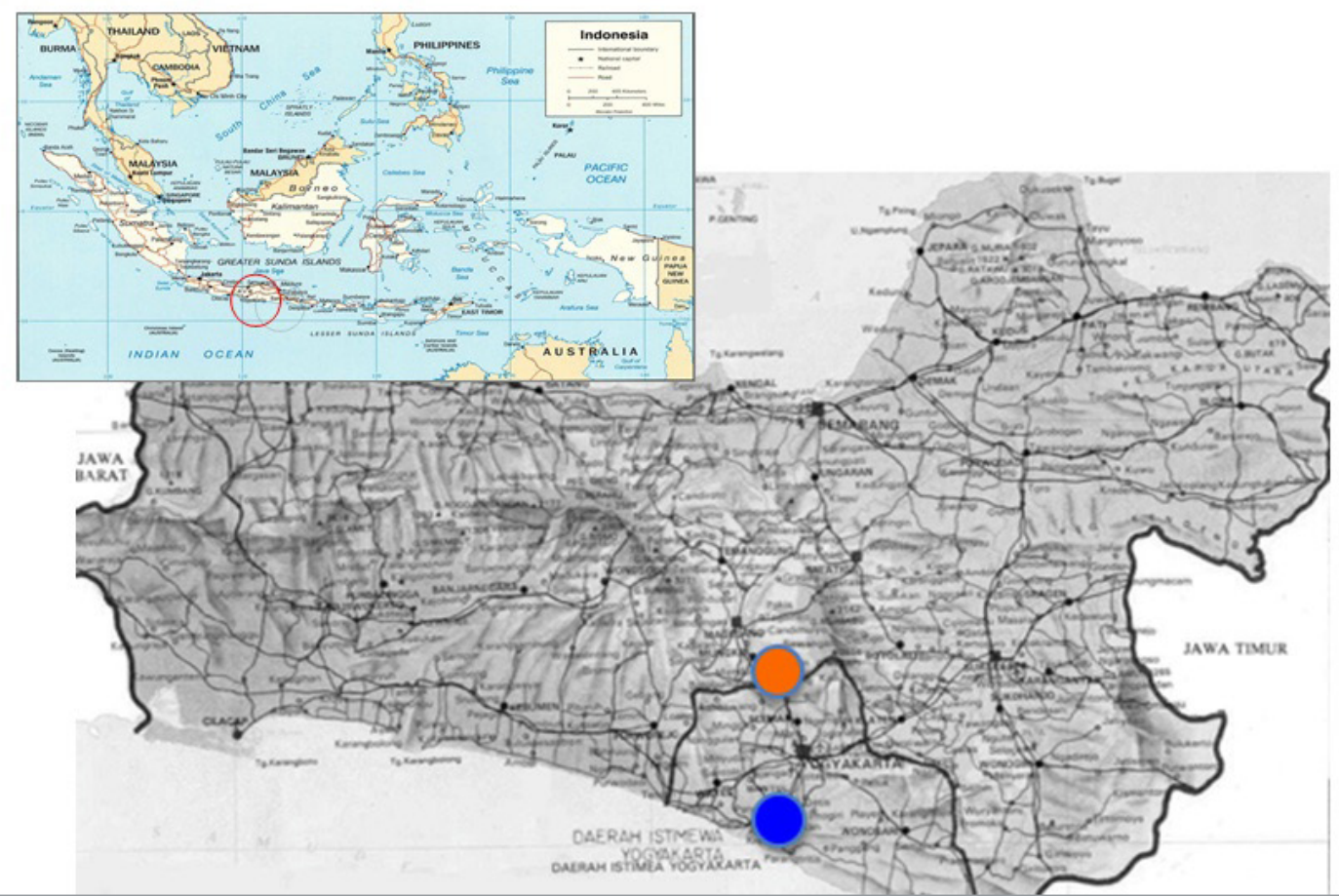

(source: http://www.lib.utexas.edu/maps/middle_east_and_asia/indonesia_pol_2002.jpg)

Figure 1. Position of research sites. 


\subsection{Research Site I-Banyakan Village}

Banyakan village was one of the areas most devastated by the earthquake in 2006, as most of the local settlements were ruined. Biogas was introduced in this village after that disaster by Gadjah Mada University Indonesia, which was supported by JICA (Japan International Cooperation Agency) in order to recover economic livelihoods. The introductory stages began with the provision of more than 10 cattle to the local community and studies in the same community gathering data to assess people's way of surviving and their well-being. In this process, Gadjah Mada University Indonesia under the implementation of Community Empowerment and Fieldwork (CEF) attempted to improve community knowledge about the economic benefits of what biogas can provide, The local facilitator is deployed to also leverage awareness and provided an understanding that the bad smells associated with cow dung are produced by aired methane-gas, which is considered hazardous to the lungs. At first placement, each of the households were offered the biogas equipment, such as 4 meters of pipe connected to with a digester, which cost around IDR 1.250.000 (though it depends on the needs of each household). It may cost IDR. 3.000.0000. Facilitators of the Gadjah Mada University first attempted to use cemented pipe, which was also implemented in Pundong village. However, it cannot sustain endured due to debilitating earthquakes. Responding to it, another biogas plant type with semi-ceramic fabricated pipes is introduced. The operating procedure is actually simpler than as imagined. $2 \mathrm{~kg}$ of cow-dung are inserted in the digester and mixed with a litre of water to ensure that the fermentation occurs. After 1-2 weeks, the biogas can be used for cooking and it is contained in the big plastic bag which can be just be compressed by a wooden stick before cooking starts.

The plastic used as a gas container is considered affordable enough because it is only IDR 25.000 for 25 meter long piece and when it is broken, each household can just purchase it at nearby construction agencies in the Bantu region. The benefit of biogas is well perceived by the local community, though only 12 households utilize it in addition to maintaining their cattle. Every $1 \mathrm{~m}^{3}$ of biogas can replace is equivalent to approximately 600 watts (1 hour usage). Regarding the risks, each user understands the possibility of explosion of biogas is low because the main substance has been gasified and fermented in the digester, so the end-outcome gas only contains methane. Besides, if they have ever attempted to make a small hole in the plastic and hold it closer to the fire, they would have figured out that explosions do not occur and the flame was minor. As long as the gas is not contained in pressurized tubes like general LPG containers, biogas is not hazardous. The maintenance procedure is considered easy for the user as they only take out residues and can use it for additional oil fertilizer. For instance, if they input 5 litres of cow dung, the final residue will be 5 litres as well, and it is very useful because they do not have to dry it, they just mix it with soil to help the plants grow. By using this residue in the same way, they save for agricultural production and have no need to buy chemical fertilizer. Food cooked with biogas is also without a bad smell and this raised good responses from 
neighbouring people. Concerning the impact on health, biogas for the local community provides health benefits because they have assessed that the number of $E$. Coli present in the water well situated adjacent to the cow stable has declined gradually until $90 \%$ were gone. This achievement should be noted for further promotion.

To support the sustainability of community finance, especially for biogas, the community leader in Banyakan proposed funding scheme to the local government after the JICA and Hi-Link project ended. During the project, each interested household paid $30 \%$ of total initial costs, and the other $70 \%$ was funded by JICA. However, according to my observation, the quality of biogas installation in Banyakan village did not gain local prominence because the users did not receive continuous training and at the initial installation stage they were not involved in the design-making. The need to uplift the quality of biogas is always at the heart of a/the community, but they must overcome financial constraints, especially for upgrading. The local institution, operated by the community, provides opportunities to disseminate information as well as exchange local aspirations and ideas at regular weekly meetings. By improving their solidarity through lending money, each household is not severely suffering from financial hurdles. However, the local government has not put forward any additional funding, nor have they even visited the site for assessment. More than three times the proposal was delivered to the local government office, but no response appeared. When asked about how government should take action, most people responded that government must be responsible for local livelihood promotion especially when dealing with prosperity and economic improvement.
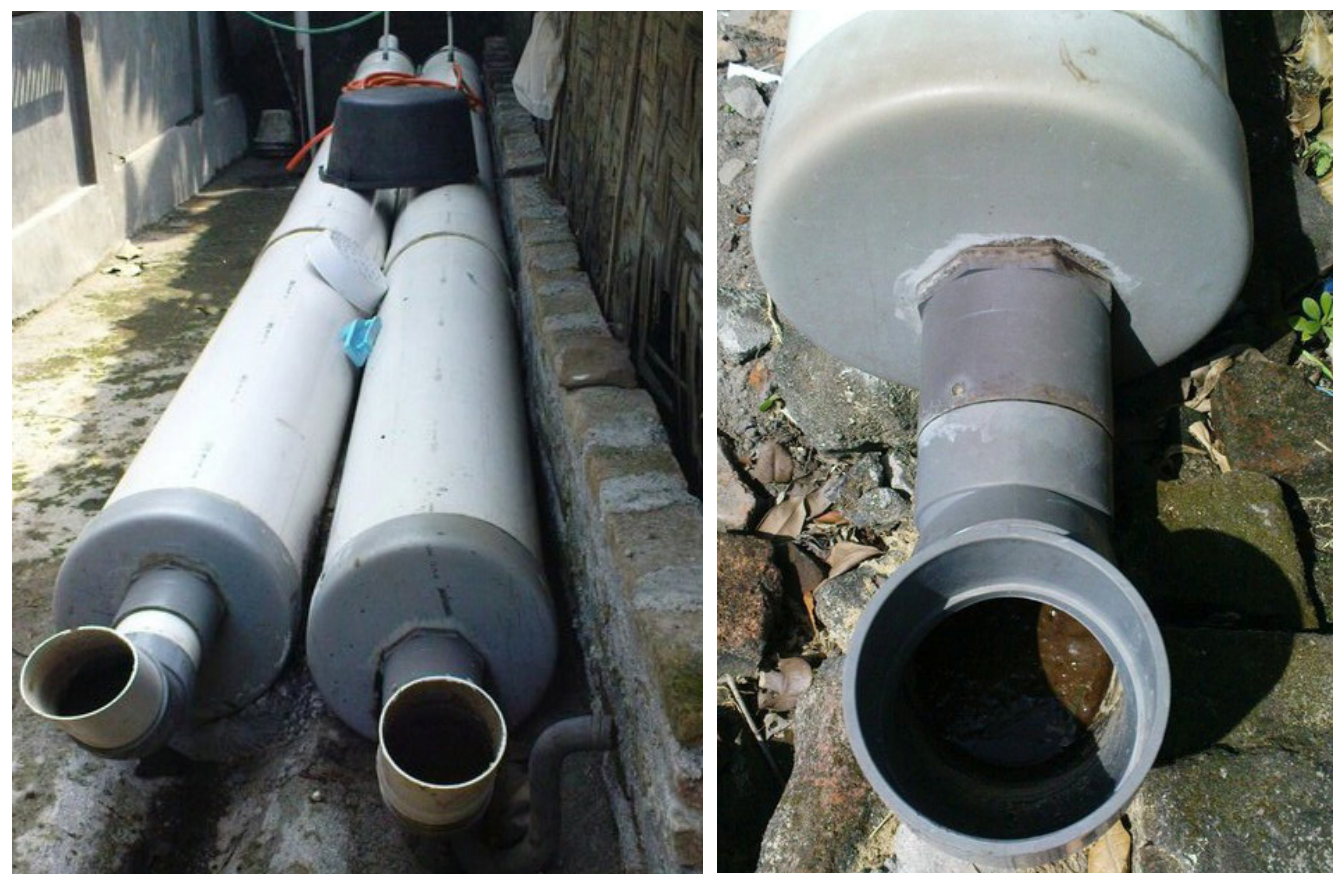

Figure 2. These PVC pipes are used by the community for the digester. They insert cow dung and water and the gasification processing will take from 1 to 2 weeks. Gadjah Mada University Indonesia's student fieldwork program (primarily students from the Livestock Department) introduced this gas plant. Japan International Cooperation Agency facilitated the initial installation by requiring only $30 \%$ of the project's capital investment from local people. 

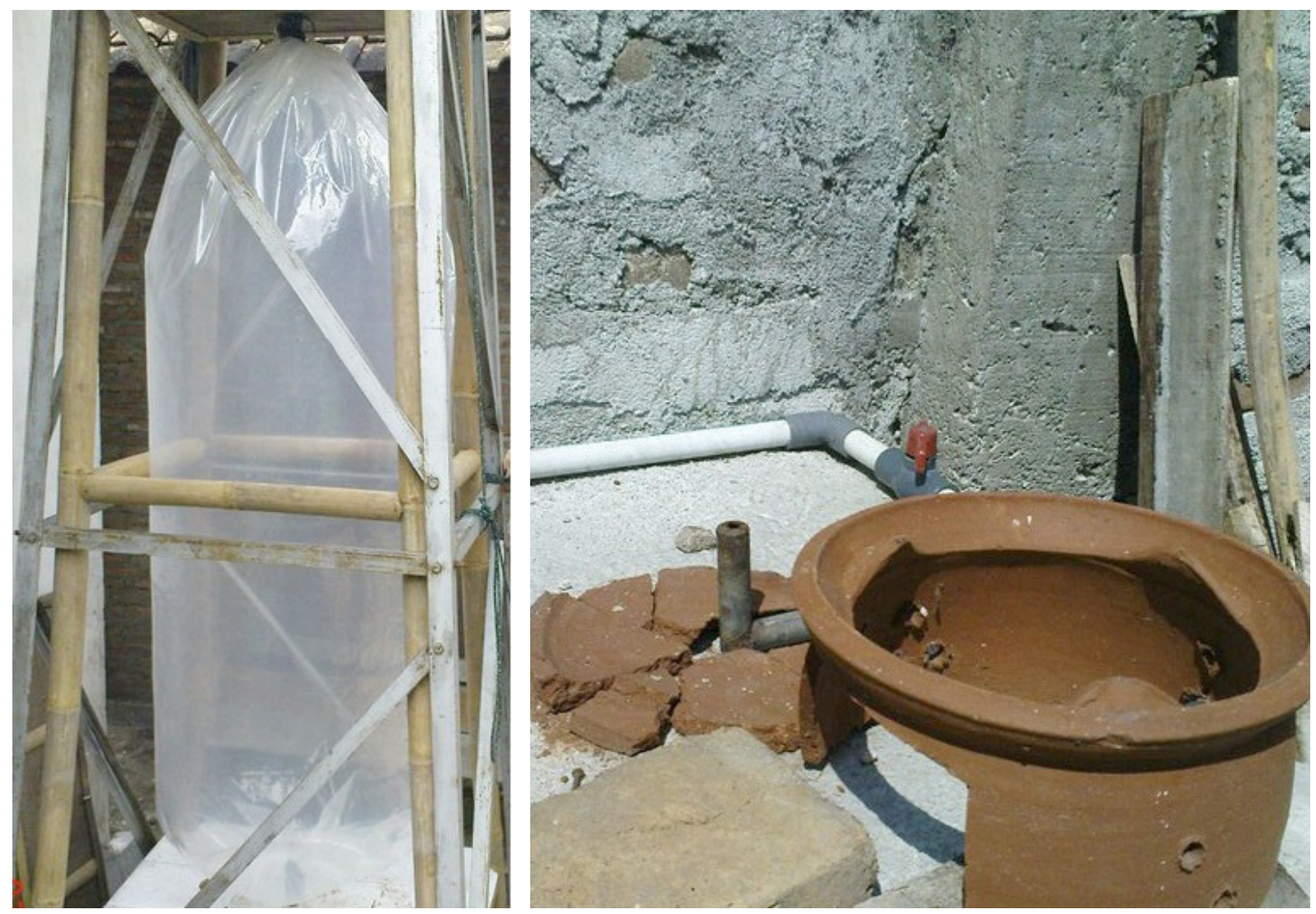

Figure 3. The plastic bag on the left contains methane gas. It is compressed from above by a wooden stick which pushes down the gas. On the right side is the end-channel of biogas used for cooking. A user can adjust the volume of gas as desired.

\subsection{Research Site II-Manis Renggo Village}

Different from research site 1, biogas in Manis Renggo village is built up based on the local needs of enterprises for converting their tofu slurry to be more productive alternative energy fuel, and the program starting-point was very similar to Banyakan Village. The tofu industry in this village provides their primary income, and the community has already targeted distribution areas for sale markets. More than 20 homemade tofu industries contribute to the economic livelihoods of the local people. When producing tofu, its slurry is extensively wasted and the residue is assessed to be potential for biogas inputs. The community considered tofu's residues negative byproducts with a disgusting smell, so often they got rid of it in the nearest river, though this was not environmentally friendly. During 20072008 Manis Renggo village hosted more than 12 students for fieldwork activities for their final study requirements. At that time, those Gadjah Mada University students introduced the mechanisms and operating procedures for implementing biogas and how to resolve that negatives associated with tofu residue, such as unpleasant odors.

As the physical setting is quite sandy, cemented pipes are used to produce biogas in this area and all equipment is easily obtained from a nearby construction agency in Klaten. Regarding the biogas, it costs the user around IDR 1.000.000 which is accessible and not did not burden them. At later stages, they are 
able to extend the installation by modifying the length of digester pipes in order to be adapted to changing local needs. From 20 biogas installations, now the numbers have increased to 60 installations, all initiated by the local community. Gadjah Mada University is often invited back by the local community for consultations and on-going assistance regarding the maintenance and modification of the digesters.

The enthusiasm of the community towards the initiative has lead to the success story of Manis Renggo Village, for not only do the local people and industry enjoy this opportunity, but also the government has been supportive. The project is supported by the The local government in Manis Renggo head of county and village chief through public consultation. The first time the student team immersed in this research, they were astonished by the warm welcome and eager greeting from the county head. He openly invited the students to come visit his house in Manis Renggo and to stay there while pursuing their research. As in the conversations with the local facilitators, the local governments are open to all proposals presented by the community. They often visited the tofu industry to see the progress and economic livelihoods and also interact with local people congenially to better understand any potential problems they might have.

\subsection{Local Participation, Government Involvement, and Other Stakeholders Involvement}

Comparing those two different areas, participating communities have distinctive needs for building up biogas installations. In the first research site in Banyakan, the community is active, but the local government has nothing to do with actions for livelihood improvement. It can be said that making positive impacts on livelihoods is not put on their development agenda. Local communities should have given opportunities to respond and transparently explained regarding what sort of required procedures and information is necessary to meet before proposals are delivered.

Meanwhile, in the second research site of Manis Renggo the local governments are relatively open to the changes made by this initiative, as they regard this project will bring financial sustainability of local economics.. These two sites actually exemplify what is so-called "institutional predicaments" can be overcome by the local governments through their supports, where the need of community to improve quality of local business meet with characteristics of biogas. Institutional predicaments are defined as local settings involving local stakeholders when one of the parties does not support the development of newly introduced technology. As part of Renewable Energy Technology (RET) framework, biogas should be taken into account as a new way of creating something for environmental and economic gain. As Painuly (2001) asserts, financial issue that may be obvious hurdle for further improvement can be altered if the government is capable of facilitating the relations of community with external actors, such as university undertaking the respective project.

Locating the positive impacts as items which attract biogas, improvement and also other benefits in making people understand and comprehend should be prioritized in order 
to give the community a chance to make a decision. Local participation shown in Manis Renggo and Banyakan implies that technology without active social capital will be no use as it does not give any benefits. The Critical importance of building a new installation that the project starts up is the new ways to ensure a degree of community ability in adapting a new technology which in later phase would be advantageous for generating sustainable livelihood. Also, local needs are only reinforced through community participation because to some extent, they will value the intrinsic benefit of the installation provided. Although biogas installation in those two sites become a success, my observation found that in the mid of installing processes, local participation is less involved, indicated by the gradual decline of biogas usage and the local return to cooking on wood situated in both research sites. Raising from this concern, Kartha and Larson (2000) assert that local needs and their technological acceptance is only able to be facilitated through local participation as it would allow them to choose the most suitable alternative energy source with locally obtainable construction materials.

It is crucial to review how social acceptance in renewable energy posits important things which are mostly ignored by some of environmental planners. The idea of social acceptances is asserted by Wustenhagen et al (2007) which consist of socio-political acceptance, community acceptance, and market acceptance. Socio-political acceptance necessitates diverging stakeholders, government and other parties to synergize their interests for concretizing the community needs. This is may be one of the biggest challenges and sometimes a major obstacle for renewable energy development, as each of the parties has different values and views to be coordinated. If this first requirement is met, subsequent process of installation will predictably run flawlessly because all of stakeholders have been broad-minded enough to accept any consequence that may come with it and in the same time they are ready enough to provide support for investors. Meanwhile, community acceptance is more substantial where it relates to by whom "sitting-decision of local stakeholder" will be executed. This will be playing a critical role in answering who local authorities are to ask for project authorization in a later stage. Also, information dissemination provided by interactive communication between actors/ users and government will lead to effective development of technology. And, another extent is market acceptance, which relates to segmentation of market for product distribution. If we put these into the context of two different research sites, Manis Renggo is more likely able to achieve socio-political acceptance and community acceptance as both aspects has heavily contributing to the improvement of biogas for production leveraging, but not in Banyakan. In the second site the community must overcome the situation by strengthening their social capital through local cooperation done with fellow members..

\section{CONCLUSION}

From the discussion and observation above, Banyakan village is less uccessful in mobilizing community members in adopting biogas installation because it has not gained 
interest of the household, but some community members still retain their usage because it is considered efficient and beneficial for organic fertilizer. Meanwhile, Manis Renggo shows differently, it has strong demand on biogas because it has contributed to the increase in profitability and also savings and its local governments.

\section{REFERENCES}

(1) Abdullah, Kamaruddin. (2005). Renewable energy conversion and utilization in ASEAN countries. Energy, 30, 119-128.

(2) Barnet, Andrew., Pyle, Leo., \& Subramaniam, S.K. (1978). Biogas Technology in the Third World: A Multidisciplinary Review. International Development. Canada.

(3) Cohani, Bindu N. (2009). Climate of Opportunity: Developing Asia's potential to address climate change. Journal of Emerging Market Economics, 1, 293-337.

(4) Da Silva, Edgar J. (1980). Biogas: Fuel of the Future?. Ambio, 9 (1), 2-9

(5) Deublein, Dieter., \& Steinhauser, Angelica. (2008). Biogas from Waste and Renewable Resources: An Introduction. Wenheim, Wiley-Vch.

(6) Karki, A.B, Shresta, J.N, Bajgain, S (ed.) (2005): Biogas As Renewable Source of Energy in Nepal: Theory and Development. Kathmandu: Biogas Support Programme.
(7) Larson, Eric., \& Kartha, Sivan. (2000). Expanding roles for modernized biomass energy. Energy for Sustainable Development, IV(3), 15-25.

(8) Painuly, JP. (2001). Barriers to renewable energy penetration: a framework for analysis. Renewable Energy, 7889.

(9) Reijenders, L. (2006). Conditions for the sustainability of biomass based fuel use. Energy Policy, 34, 863-876.

(10) Saha, Pranesh Chandra. (2003). Sustainable energy development: a challenge for Asia and the Pacific region in $21^{\text {st }}$ century. Energy Policy, 31, 1051-1059.

(11) Wahyuni, Sri. (2008). Policy Analysis on Biogas Development for Individual Based Alternative Energy and Farm Group (in Indonesian). Unpublished Master Thesis Institute Pertanian Bogor.

(12) Widodo, Teguh Wikan., \& Hendriadi, Agung. (2005). Development of Biogas Processing for Small Scale Cattle Farm in Indonesia. Paper presented in International Seminar on Biogas Technology for Poverty Reduction and Sustainable Development 18-20 October 2005 in Beijing China.

(13) Wustenhagen, Rolf., Wolsin, Maarten., \& Burer, Jean Mary Bürer. (2007). Social acceptance of renwable energy innovation: An Introduction to the concept. Energy Policy, 35, 26832691. 